J. Japan, Assoc, Min.

Petr. Econ. Geol.

71, $363-373,1976$.

\title{
PETROCHEMISTRY OF THE SAKAINOKAMI PLUTONIC BODY, KITAKAMI MOUNTAINS, NORTHEASTERN JAPAN
}

\author{
Yuzo KaTo \\ Faculty of Science, Tohoku University, Sendai \\ SaTOShI HAMA \\ Suncok Cansultants Co., Ltd., Tokyo
}

\begin{abstract}
Sakainokami plutonic body is one of the many Cretaceous intrusive bodies in the northern Kitakami mountains. The present study revealed that the plutonic body is composed of three rock types, namely; type A, type B and type $C$, which have been emplaced successively in that order. Types $A$ and $C$ are further subdivided into three and two subtypes, respectively, as follows:

Type A

Subtype A-1: Biotite-bearing olivine augite hornblende gabbro

Subtype A-2: Biotite, hypersthene-bearing augite hormblende gabbro

Subtype A-3: Augite-bearing biatite hornblende gabbro

Typв B: Augite-bearing biotite hornblende gabbro-diorite

Type C

Subtype C-1: Biotite hornblende monzodiorite-granodiorite

Subtype $\mathrm{C}-2$ : Biotite hornblende granodiorite.

Within subtypes A-2 and A-3, two groups differing in the crystallization sequence of plagioclase and hornblende are identified. In one group, hornblende has crystallized earlier than plagiociase and there is an accumulation of more hornblende than normally. In the other group, plagioclase has crystallized earlier than hornblende and there is an accumulation of opaque minerals in certain portions. The former group is designated as group $\mathrm{h}$ and the latter is designated as group $\mathrm{p}$.

Without considering the presence of these groups the plots of type A rocks are segregated in accordance with these groupings three different trends emerge. These trends are designated as trend I, trend II and trend III. Trend I represents the case where there is accumulation of hornblende; trend II, where there is accumulation of opaque mineral; and trend III, representing the calc-alkaline trend.
\end{abstract}

\section{INTRODUCTION}

With respect to the Sakainokami plutonic body, Kanaya (1974) has reported the $\mathrm{K}_{2} \mathrm{O}$, Th and $\mathrm{U}$ contents and the magnetic susceptibility of eight rock samples. Aside from this, no other petrographical or petrological works have been done on this plutonic body.

In general, the granitic bodies of Kita- kami mountains are divided into two groups: one is accompanied by gabbroic rocks and the other is not. Those accompanied by gabbroic rocks are further classified into one wherein gabbroic rocks occupy only a small part, and another where gabbroic rocks occupy a considerable part. The Sakainokami body belongs to the latter class. In this paper petrography and petrochemistry of this body are presented. 


\section{Geologic Setting}

The Sakainokami plutonic body is a small intrusive body of Cretaceous age, about $4 \mathrm{~km}$ wide and $13 \mathrm{~km}$ long, situated in the northern Kitakami mountains. The body has been intruded into Permian rocks consisting mainly of slate, chert and sandstone. Contact metamorphism on the sediments is clearly manifested (Fig. 1). The plutonic body cuts the general strike $\left(\mathrm{N} 40^{\circ} \mathrm{W}\right)$ of wall rocks disharmonically. It

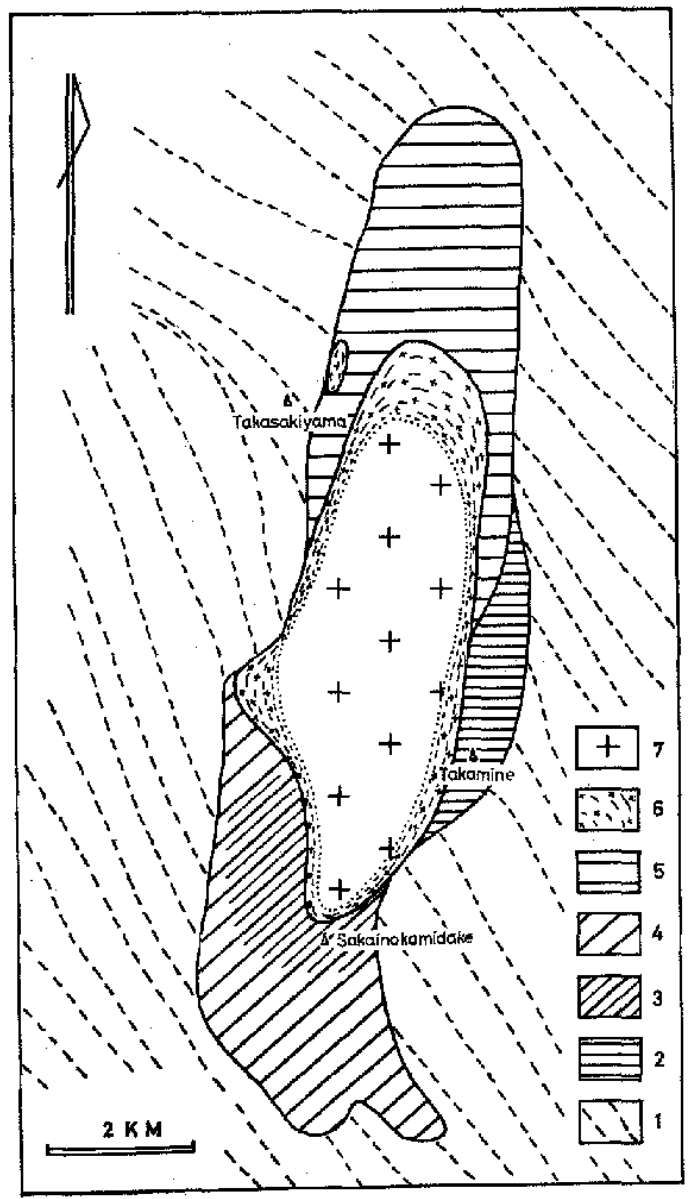

Fig. 1 Geologic map of the Sakainokami plutonic body.

1: Permian rocks, 2: Subtype A-1, 3: Subtype A-2, 4: Subtype A-3, 5: Type B, 6: Subtype C-1, 7: Subtype $\mathrm{C}-2$ is elongated along the $\mathrm{N} 10^{\circ} \mathrm{W}$ direction, roughly coinciding with the general direction of zonal arrangement of the granitic bodies in the northern Kitakami mountains (Katada et al., 1971).

The plutonic body is composite. Based on the present field and microscopic observations, three intrusive units are identified, namely: types $\mathrm{A}, \mathrm{B}$ and $\mathrm{C}$ (see Fìg. 1). Based on petrographic characteristics, type $C$ is divided further into subtypes, $\mathrm{C}-1$ and $\mathrm{C}-2$, which are gradational. Subtype $\mathrm{C}-1$ corresponds to the marginal facies of type C. It is characterized by heterogeneity of rock-facies, and various grades of foliation. It is finer in grain-size and darker in color than subtype $\mathrm{C}-2$, which constitutes the central part. In general, the strike of foliation is subparallel to the boundary between the two subtypes and the dip is nearly vertical. Subtype $\mathrm{C}-2$ shows little foliation and $\mathrm{K}$-feldspars are frequently pink in hand specimen. In contrast, the feldspars of $\mathrm{C}-1$ is always colorless. Subtype $\mathrm{C}-1$ is about 50 to $500 \mathrm{~m}$ in width, mantling subtype $\mathrm{C}-2$.

Based on the presence or absence of olivine and the mode of occurrence of pyroxene in thin sections, type $A$ is also further subdivided into three subtypes, $\mathrm{A}-1$, $\mathrm{A}-2$ and $\mathrm{A}-3$. Their boundaries are however difficult to discriminate in the field. Olivine is contained only in subtype A-1. In subtype A-2, some or many crystals of pyroxene is not rimmed by hornblende, while all pyroxene crystals in subtype A-3 are thickly mantled by hornblende.

At $0.5 \mathrm{~km}$ east of the Otaki Falls and at Takinaru, blocks of the A type rocks are penetrated by the subtype $\mathrm{C}-2$ rocks, showing that subtype $\mathrm{C}-2$ is younger than type A. Although no other field evidence was found to indicate direct relation among the 
other types, it seems that type $A$ is the oldest and type $C$ is the youngest of the three types.

In general, the Sakainokami rocks are inedium to fine-grained, suggesting that this body belongs to shallow intrusive type.

\section{Petrography}

\section{Microscopic observation}

The three rock types constituting the plutonic body are described below.

(1) Type A

Subtype A-2 and A-3 rocks have similarities in terms of mineral assemblage and other microscopic characteristics. Subtype A-1 is distinctly different. Therefore, subtype A-1 is described at first, and then other two subtypes are done collectively.

a. Subtype A-1

Biotite, oilvine(-bearing) augite hornblende gabbro

Biotite-bearing hornblende augite gabbro

Plagioclase is mainly prismatic and euhedral to anhedral.

Hornblende is brown colored and subhedral to anhedral. Well-formed plagioclase laths are partially or mostly enclosed within Iarge grains of homblende, resembling ophitic relation between pyroxene and plagioclase. When the relation between homblende and plagioclase is similar to the ophitic or subophitic relation between pyroxene and plagiociase, the texture is hereinafter expressed as "ophitic" or "subophitic", respectively. Poikilitic inclusions of plagioclase, augite and opaque minerals are cornmon. These textural relations indicate that plagioclase and augite have crystallized earlier than hornblende.

Augite occurs as isolated crystals or core in larger hornblende. In the former case, augite is euhedral to subhedral. Oftentimes, subophitic texture is observed. Some crystals are rimmed by hornblende, whereas the others are bare. Sometimes poikilitic inclusions of plagioclase are observed.

In hornblende crystals, augite occurs as poikilitic inclusion or as relict core. The former case is more frequent than the latter. While the augite in the former case is euhedral to subhedral, that of the latter is subhedral and the c-axes of core augite and margin hornblende are parallel.

Olivine is subhedral and generally surrounded by hornblende, augite or opaque mineral. Frequently weak undulatory extinction is observed. Inclusion of granular opaque crystal with or without green spinel is not uncommon. Rarely, aggregates of granular olivine with some green spinel is observed.

Opaque minerals occur in four modes, namely: (1) irregular shaped aggregate fringing olivine, (2) granular crystals in augite or hornblende, (3) vermicular shaped crystals in homblende, and (4) ragged acicular shaped crystals in hornblende or augite.

Green spinel is rare and occurs in contact with olivine or opaque mineral. Sometimes it is embraced by hornblende.

Biotite is also rare and occurs in hormblende or as the rim of opaque mineral.

b. Subtype A-2 and A-3

Subtype A-2

Biotite-bearing (hypersthene) augite homblende gabbro

Subtype A-3

Biotite(-bearing) hornblende gabbro

Biotite, augite-bearing hornblende gabbro

Biotite, augite-bearing hornblende monzogabbro

Augite-bearing biotite hornblende mon- 


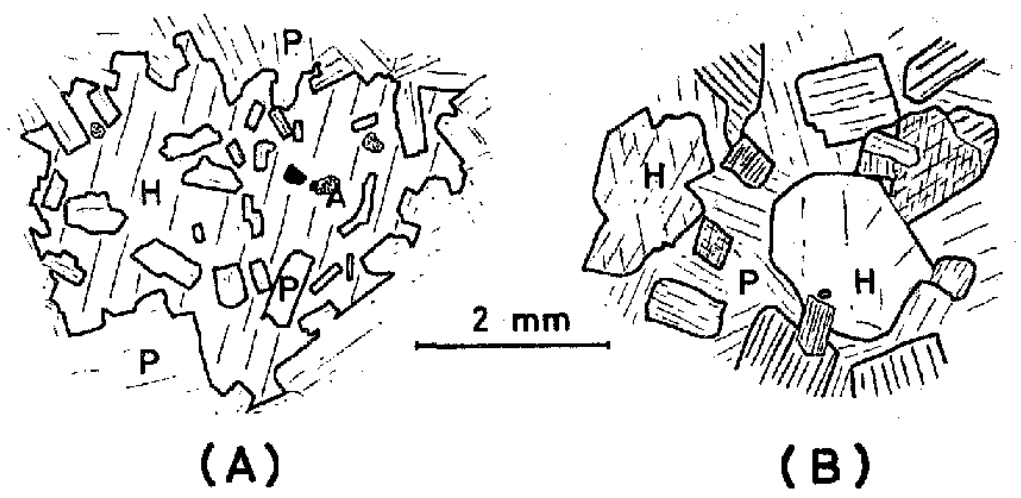

Fig. 2 Sketches showing the difference of crystallization sequence of plagioclase and hornblende.

$\mathrm{H}$ : hornblende, P: plagioclase, A: augite

(A) Rock of group p (sample number: 82303)

"Ophitic" and "subophitic" relation between euhedral to subhedral plagioclase and unhedral hornblende is shown. In the latter mineral, poikilitic inculsions of lath-shaped plagioclase is observed. Those of augite and opaque mineral are also present.

(B) Rock of group $h$ (sample number: Os 3A)

Euhedral to subhedral hornblendes are surrounded by subhedral plagioclase. "Subophitic" relation is observed. Poikilitic inclusion of little plagioclase is rarely present.

zodiorite

Plagioclase is mainly prismatic and euhedral to subhedral.

Hornblende is generally green to greenish brown in $Z$-axial color and often brownish in core and greenish in rim.

The hornblende crystals in both subtypes occur in two modes. One mode is in the form of euhedral or subhedral hornblende including a small amount of poikilitic plagioclase. The other mode is in the form of subhedral or anhedral hornblende with "ophitic" to "subophitic" relation and contains commonly poikilitic inclusions of plagioclase (Fig. 2). From these microscopic observations it is strongly suggested that hornblende has crystallized earlier than plagioclase in the first mode and later in the second mode. Hereinafter the rocks whose hornblende has crystallized earlier than plagioclase are called group $h$ and the reverse group $p$.
Hence, subtype A-1 belongs to group p. The symbol $p$ or $h$ is affixed with the symbol A-2 and A-3 to indicate the group, e.g.: group $\mathrm{h}$ of subtype $\mathrm{A}-2$ is expressed as A2h. In the field, these two groups of subtypes A-2 and A-3 rocks are exposed too irregularly that their distribution cannot be represented on the map.

Augite is euhedral to subhedral. In subtype A-3, augite always occurs as small relict core of hornblende. Those in subtype A-2 show various modes in thin section. They are either similar to those in subtype $A-3$, or mantled by thin hornblende, or occurs as separate grains. In both A-2 and $A-3$ subtypes, the ratio of separate augite grains to total augite content is larger in group $p$ rocks than in group $h$ rocks. Poikilitic inclusions are not observed. The mode of occurrence of augite in hornblende are similar to those described in subtype A-1 rocks. 
Hypersthene, with distinct pleochroism, is found only in A2p rocks and mostly surrounded by thin hornblende.

Biotite is rare and occurs as inclusions in hornblende or as crystals isolated from homblende.

As accessory minerals, quartz and $\mathrm{K}$ feldspar occur interstitially among other minerals.

\section{(2) Type B}

Augite-bearing biotite hornblende monzodiorite

(Augite-bearing) biotite hornblende gabbro (Augite, ) biotite-bearing hornblende gabbro Biotite hornblende gabbro

Plagioclase is mainly prismatic and etuhedral to subhedral.

Hornblende is euhedral and "subophitic" to "ophitic" relation to plagioclase. Generally the $Z$-axial color is green to greenish brown and often brownish in core. Poikilitic inclusions of plagioclase are sometimes recognized, while those of augite rare.

Augite occurs, but rarely, in homblende crystals either as relict core or as poikilitic inclusion.

Biotite occurs either in hornblende or as individual grains.

Quartz and K-feldspar are generally rare, occuring interstitially among other

Table 1. Average modal compositions of each division of the Sakainokami plutonic body.

\begin{tabular}{|c|c|c|c|c|c|c|c|c|c|c|c|c|}
\hline & $A$ & A-1 & $A-2$ & Azh & $A 2 p$ & $A-3$ & As̆h & $a_{\mathrm{F}}$ & $B$ & c & $c \cdot 1$ & $c-2$ \\
\hline Guarez & 1.8 & - & 1,2 & 1.4 & 1.0 & 2.6 & 1.2 & 3,6 & 7,5 & 20,3 & 16.0 & 23.7 \\
\hline$\pi$-feldspar & 1,1 & - & 0.3 & - & 0.4 & 2.5 & 3.9 & 1.6 & 3.4 & 14,8 & 10.6 & 18.0 \\
\hline 'Hagtoclase & 42,2 & 51.1 & Nh.1 & 29.2 & 47.1 & 10.2 & 31.8 & 45.8 & 51.1 & 46.2 & 48.1 & 44.8 \\
\hline 010t1te & 1.0 & 0.1 & 0.5 & tr & 0.9 & 2,7 & 0.9 & 2.2 & 2.2 & 3.7 & 4.8 & 2.9 \\
\hline Harnbiende & 46.0 & 23.9 & 47,2 & 64.1 & 38.7 & 51,9 & 61.0 & 45.9 & 34.8 & 14,0 & 19.4 & 9.7 \\
\hline Augite & 5.7 & 17.2 & B. 4 & 190 & 9.9 & 0,4 & 0.9 & 0.1 & 0.1 & tr & tr & - \\
\hline Hyersthen & 0.2 & * & 0.2 & 0,6 & 0.8 & - & - & - & - & . & - & $\cdot$ \\
\hline Divine & 0.2 & $\therefore 1$ & $\cdot$ & - & “ & - & - & $\therefore$ & $\therefore=$ & 0 & - & $\because$ \\
\hline Dpaque & 1.5 & 5.8 & 0.9 & 0.2 & 1.3 & 0.8 & 0.3 & 0.7 & 0.5 & 0.9 & 1.0 & 0.8 \\
\hline Ochers & 0.1 & Ir & - & 0.1 & II & e.1 & tr & 0.1 & 0.6 & 0.1 & 0.1 & 0.1 \\
\hline Color Index & 54.6 & 48.9 & 57.4 & 69.4 & 51.5 & 54,7 & 63.1 & 40.0 & $38: 2$ & 18.7 & 25.3 & 13.5 \\
\hline No.of Aver. & 19 & $\bar{j}$ & 6 & 2 & 4 & 10 & 4 & 6 & 10 & 23 & 20 & 13 \\
\hline
\end{tabular}

crystals.

(3) Type $\mathrm{C}$

Subtype $\mathrm{C}-1$

(Augite-bearing) biotite hornblende granodiorite

Augite-bearing biotite hornblende monzodiorite

Subtype $\mathrm{C}-2$

Biotite hornblende granodiorite

Biotite (-bearing) hornblende adamellite

Plagioclase is mainly prismatic and

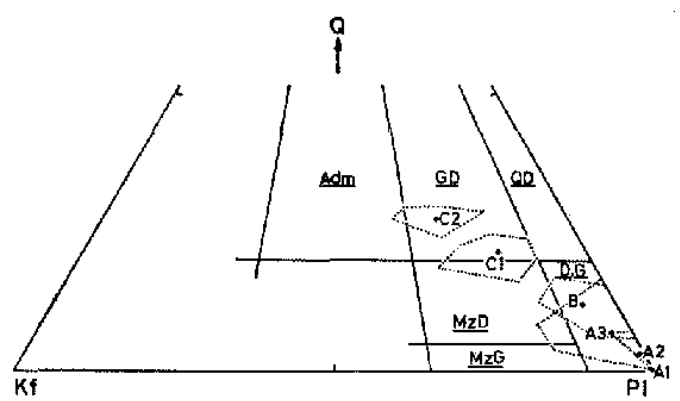

Fig. 3 Modal quartz-K-feldspar-plagioclase triangular diagram showing the nomenclature used in this paper.

Dotted line: limit of distribution, Adm: adamellite, GD: granodiorite, QD: quartzdiorite, $\mathrm{MzD}$ : monzodiorite, MzG: monzogabbro, D: diorite, G: gabbro, + : average composition of each type or subtype. Compositional field of A-2 subtype fully overlaps with that of A-3 subtype. Rock names are underlined.

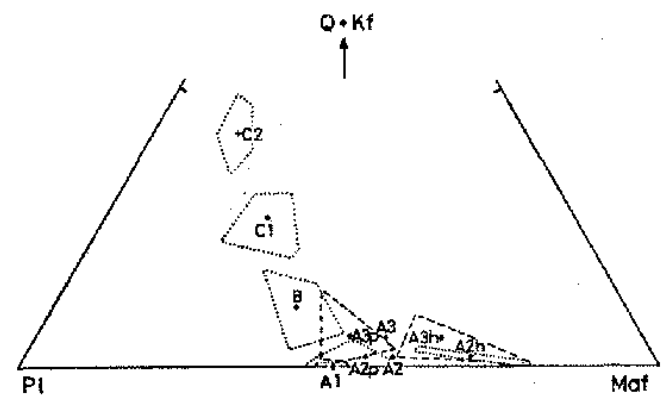

Fig. 4 Modal (quartz + K-feldspar) - plagioclasemafic minerals triangular diagram. + : average modal composition; Dotted and broken line: limit of distribution 
Table 2. Chemical compositions of rocks composing

\begin{tabular}{|c|c|c|c|c|c|c|c|c|c|c|c|c|c|c|c|c|c|c|c|}
\hline $\mathrm{Na}$ & 1 & 2 & 3 & 4 & 5 & 6 & 7. & 8 & 9 & 10 & & & 13 & 14 & 15 & 6 & 17 & 8 & 9 \\
\hline pin. & $3-2$ & $3-1$ & 302 & 1 & -5 & 1 & 303 & 504 & 608 & 81609 & 66 & $B A$ & 2 & 97 & 84 & $3 x$ & $0 g-3$ & 20 & 81519 \\
\hline $\mathrm{SiO}_{2}$ & 41.35 & 1.80 & 45.02 & .07 & 45.36 & 46.59 & 47,88 & 48.37 & 48.40 & 49.17 & 49.39 & 49.72 & 50.42 & 51,46 & 53.67 & 4.20 & 55.25 & 56.04 & 8.70 \\
\hline $\mathrm{TiO}_{2}$ & 0.79 & 0.97 & 0.98 & 1.00 & 1.39 & 0.85 & 0.79 & 0.74 & 0.60 & 0.74 & 0.69 & 0.97 & 0.96 & 0.82 & 0.77 & 0.69 & 0.84 & 0.60 & 0.62 \\
\hline $\mathrm{Al}_{2} \mathrm{O}_{3}$ & 19.41 & 9.58 & 14.03 & 17.91 & 15.64 & 16.73 & 16.22 & 16.78 & 11.82 & 15.28 & 15,82 & 14.86 & 13.94 & 17.24 & 17,86 & 16.74 & 17.65 & 15.82 & 17.86 \\
\hline $\mathrm{e}_{2} \mathrm{O}_{3}$ & 5.47 & 5.29 & 2.88 & 4.44 & 3,32 & 3.06 & 2.84 & 2.29 & 3.15 & 3.46 & 2.25 & 2.62 & 3.12 & .72 & 2,49 & 2.40 & 2.45 & 84 & 2.31 \\
\hline 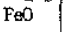 & 6.76 & 6.92 & 6.57 & 6.69 & 6.79 & 6.56 & 6.88 & 7.19 & 6.52 & 6.51 & 7.10 & 6.60 & 6.30 & 5,47 & 5,96 & 5.15 & 4.61 & 5,73 & 3.40 \\
\hline 0 & 0.15 & 17 & 6 & $2 I$ & 7 & 0.1 & 0.17 & 0.19 & 0.18 & & 2 & & 1.9 & 6 & 0.14 & 0.15 & 0.13 & .12 & 1.11 \\
\hline $\mathrm{MgO}$ & 7.77 & 7.08 & 11.96 & 7.84 & 99 & 9.22 & 8.29 & 8.97 & 13.63 & 8.81 & 14 & 8 & 40 & 6 & 4.90. & 5.93 & 4. & 32 & .18 \\
\hline 0 & 14,89 & 14.15 & 13.82 & 12.08 & 11.71 & 10.91 & 11.64 & 9.90 & 10.61 & 9.65 & 10.26 & & 37 & 09 & 7.43 & 8,16 & 7 & 2 & 5.95 \\
\hline $\mathrm{Na}_{2} \mathrm{O}$ & 1.42 & 1.61 & 1.47 & 2.47 & 2.04 & 2.42 & 2.50 & 2. & 1.80 & 2.36 & 37 & 2.60 & 42 & 2.95 & 3.06 & 3.06 & 3.36 & 2.67 & $3 ; 90$ \\
\hline $\mathrm{K}_{2} \mathrm{O}$ & 0.37 & 0.38 & 0.70 & 0.59 & 0.95 & 0.71 & 0.40 & 0.76 & 0.74 & 0.96 & 0.65 & 1.54 & 1.75 & 1.48 & 1.80 & 1.93 & 2.58 & 2.02 & 2.46 \\
\hline $\mathrm{H}_{2} \mathrm{O}+$ & 1.88 & 1.81 & 2.24 & 1.76 & 2,25 & 2,34 & 1.68 & 2.12 & 2.70 & 2.59 & 2.13 & 2.18 & 2.28 & 1,57 & 1.45 & 3.39 & 1.35 & 2,19 & 0.99 \\
\hline $\mathrm{H}_{2} \mathrm{O}-$ & 0.20 & 0.15 & 0.16 & 0.13 & 0.18 & 0.20 & 0.32 & 0.21 & 0.31 & 0.36 & 0.23 & 0.12 & 25 & .24 & 0.25 & 0.14 & 0.16 & 0.20 & 0.10 \\
\hline $\mathrm{P}_{2} \mathrm{O}_{5}$ & tr & 0.18 & 0.06 & 0.20 & .14 & 0.16 & 0.21 & 0.20 & .12 & .28 & .14 & 0.11 & 18 & 20 & 0.25 & 0.23 & 0.23 & 19 & 0.18 \\
\hline tal & 100,461 & 100,09 & 100 & 100.39 & 99.93 & 9 & 2 & 6 & 10 & 10 & & & 58 & & 1 & $9.17^{\prime}$ & 100.61 & 9.66 & 99.76 \\
\hline Q & & & & & & & & & & & & & & & .88 & 07 & & & .98 \\
\hline or & 2.17 & & & 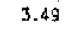 & & & 6 & 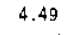 & 7 & & 4 & & 10.34 & & & $1.4]$ & & 94 & 24.53 \\
\hline$A b$ & 2.20 & 6.87 & 7.44 & 16.58 & 24,64 & $20.4 \mathrm{~B}$ & 19.46 & 18.11 & 15.23 & 19.97 & 20.06 & 21.97 & 20.48 & 24.96 & 25,90 & 25.89 & 28.42 & 22.59 & 33,00 \\
\hline An & 45.50 & 45.09 & 29.62 & 36.05 & 30.70 & 32.69 & 32.77 & 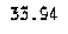 & 21.99 & 28.27 & 30.61 & 24.06 & 22.02 & 9.44 & 29.48 & 26.25 & 25.45 & 5.21 & 3.96 \\
\hline $\mathrm{Ne}$ & 5.31 & 3.66 & 70 & 2.32 & 42 & & & & & & & & & & & & & & \\
\hline (No) & 11.83 & 9.98 & 16,10 & 9.42 & 11.06 & 8 & 4 & 0 & 1 & 2 & 10 & & 9.71 & & 8 & 32 & 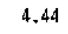 & & .82 \\
\hline Di $\operatorname{En}_{1}$ & 8.05 & 6.61 & 11.46 & 6.33 & & 5.75 & 6.33 & 3.69 & 9.02 & 5.00 & 5.08 & 6.06 & 6.53 & .96 & 1.38 & 3.43 & 2.81 &, 46 & 3.17 \\
\hline fFs & 2.86 & 2.65 & 3.22 & 2,37 & 2.42 & $2 . \lambda 1$ & 2.85 & 1.73 & 2.31 & 1.87 & 2.53 & 2.40 & 2.44 & .62 & 0,90 & 1.54 & 1.35 & 1.69 & 0,53 \\
\hline $\mathrm{E} \pi$ & & & & & & 0.70 & 7.18 & 11.93 & 10.58 & 23.98 & 12.96 & 5,87 & 11.93 & 22.29 & 10.82 & 12.34 & 8.22 & 55 & 6.75 \\
\hline & & & & & & 0.26 & 3.23 & 5.49 & 2.70 & 5.23 & \$, 94 & 2.32 & 4.42 & 5.08 & 6.99 & 5.07 & 3.96 & 6.54 & 2.98 \\
\hline & 7.91 & 7.72 & 12.83 & 9.25 & 12.03 & 11.57 & 4.99 & 4.78 & 10.05 & 2.08 & 2.79 & 7.11 & 1.73 & 0.07 & & & & & \\
\hline & 3.09 & 3.40 & 3.98 & 3.94 & 4.11 & 4.71 & 2.48 & 2.48 & 2,85 & 0,85 & 1. .53 & 3.09 & 0.71 & 0.03 & & & & & \\
\hline $\mathrm{Ntt}$ & 7.94 & 7.66 & 4.17 & 6.44 & 4.81 & 4.44 & 4.12 & 3.32 & 4.57 & 5.02 & 3.26 & 3.80 & 4.52 & .94 & 1 & 48 & 4 & 7 & 3.35 \\
\hline II & 1.50 & 1.84 & .87 & 1.90 & 2.64 & 1.61 & 1.50 & 1.41 & 1.14 & 1.41 & 1,31 & 1.84 & 1.82 & .56 & 1.46 & 1.31 & 99 & .14 & .18 \\
\hline Ap & $t$ & .43 & 0.13 & 0.46 & 32 & 0.37 & 0.49 & 0.46 & 28 & 65 & .32 & 26 & 42 & 46 & .59 & 0.53 & 0.53 & 0.44 & 0.42 \\
\hline D.I. & $\begin{array}{c}7.00 \\
\end{array}$ & 76 & 14.26 & 22.39 & 61.00 & 24.68 & .82 & 20,00 & 19.60 & 2.2 & 90 & 55 & 30.82 & 70 & $0 . B O$ & 40.37 & 7.21 & 43.24 & $50,0.4$ \\
\hline vis. & A & & $\mathrm{A} 2 \mathrm{~h}$ & $A .2 p$ & & & & & & & & & & 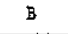 & 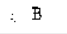 & Asp & B & 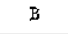 & 1 \\
\hline
\end{tabular}

1. Biotite-br, olivine augite hornblende gabbro (quartz free), $300 \mathrm{~m}$ ESE of the Mt. Takamine

2. Olivine-br, augite hornblende gabbro (quartz free), $300 \mathrm{~m}$ ESE of the Mt. Takamine

3. Augite hornblende gabbro (quartz free), $900 \mathrm{~m} \mathrm{ESE}$ of the Mt. Akatamori

4. Biotite, hypersthene-br. augite hornblende gabbro, top of the Mt. Sakainokami-dake

5. Biotite-br. augite hornblende gabbro, $1.3 \mathrm{~km}$ WNW of the Mt. Sakainokami-dake

6. Biotite-br. augite horublende gabbro (quartz free), $1.4 \mathrm{~km}$ NW of the Mt. Sakainokami-dake

7. Biotite hypersthene augite hornblende gabbro, (quartz free), $750 \mathrm{~m} \mathrm{E}$ of Mt. Akatamori

8. Augite-br. biotite hornblende gabbro, $1.6 \mathrm{~km}$ WSW of the Mt. Sakainokami-dake

9. Biotite-bearing angite hornblende gabbro, $1.6 \mathrm{~km}$ SSW of the Mt. Salkainokami-dake

10. Augite-br. biotite hornblende gabbro, $1.5 \mathrm{~km}$ SSW of the Mt. Sakainokami-dake

11. Augite-br. biotite hornblende gabbro, $1.5 \mathrm{~km} \mathrm{SW}$ of the Mt. Sakainokami-dake

$12 \& 13$. Augite, biotite-br. hornblende monzogabbro, $3.1 \mathrm{~km}$ WNW of the Mt. Takamine

14. Augite-br. biotite hornblende diorite, $850 \mathrm{~m}$ ENE of the Mt. Takasaki-yama

15. Augite-br. biotite hornblende monzodiorite, $900 \mathrm{~m} \mathrm{~N}$ of Oginosawa hamlet

16. Augite-br. biotite hornblende monzodiorite, $600 \mathrm{~m} \mathrm{E}$ of the Mt. Akatamori

17. Angite-br. biotite hornblende diorite, $700 \mathrm{~m} \mathrm{NW}$ of Oginosawa hamlet

18. Biotite hornblende diorite, $1 \mathrm{~km}$ WSW of the Otaki Fall

19. Biotite hornblende monzodiorite, Osada

20-29. Biotite hornblende granodiorite,

20-22, 28. From an outcrop, $2.2 \mathrm{~km} \mathrm{NE}$ of the Mt. Akatamori. 28: Differentiated part

23. $1.8 \mathrm{~km}$ NNE of the Mt. Akatamori

24. $60 \mathrm{~m} \mathrm{~S}$ of the Otaki Fall

25. $500 \mathrm{~m} \mathrm{~W}$ of the Otaki Fall

26. $2.1 \mathrm{~km} \mathrm{NE}$ of Mt. Akatamori

27. $2.2 \mathrm{~km} \mathrm{NW}$ of the Mt. Takamine

29. $400 \mathrm{~m} \mathrm{E}$ of the Otaki Fall 
the Sakainokami plutonic body.

\begin{tabular}{|c|c|c|c|c|c|c|c|c|c|}
\hline 20 & 21 & 22 & 23 & 24 & 25 & 26 & 27 & 28 & 29 \\
\hline $0 \leqslant-B$ & $Q_{s-A}$ & $\mathrm{Os}-\mathrm{C}$ & 81805 & 8155 & Tk-1 & 544 & B71 & $0 \leq-1)$ & Hk -4 \\
\hline 58.85 & 59.04 & 59.33 & 60.18 & 63,56 & 63.87 & 64.47 & 64.51 & 64.52 & 66.74 \\
\hline 0.56 & 0.55 & 0.58 & 0.55 & 0.40 & 0.39 & 0.39 & 0.39 & 0.39 & 0.32 \\
\hline 15.29 & 16.55 & 16.85 & 17.19 & 15.81 & 15.79 & 15.48 & 15.28 & 15.88 & 15.42 \\
\hline 2.47 & 2.32 & 1.91 & 2.39 & 1.61 & 1.23 & $2.6 \mathrm{~B}$ & 1.46 & I. Bg & 1.77 \\
\hline 4.08 & 3.85 & 4.06 & 3.29 & 2.91 & 3.99 & 2.35 & 3.72 & 2.73 & 2.27 \\
\hline 0.12 & 0.12 & 0.11 & 0.11 & 0.07 & 0.08 & 0.07 & 0.09 & 0.09 & 0.08 \\
\hline 3.99 & 4.11 & 3,82 & 3.30 & 2.34 & 2.25 & 2.32 & 2,29 & 2.28 & 1.90 \\
\hline 6.08 & 6.22 & 6.00 & 5.81 & 4.66 & 4.68 & 4.03 & 4.62 & 4.37 & .3 .85 \\
\hline 3.52 & 3.71 & 3.20 & 3.49 & 4.08 & 3.11 & 3.95 & 3,11 & 3.43 & 3.12 \\
\hline 2.05 & 1.80 & 2.26 & 2.53 & 2.82 & 3.01 & 2,97 & 2.65 & 2.78 & 3.12 \\
\hline 1.20 & 1.21 & 1.22 & 1.02 & 1.08 & 0.92 & 0.94 & 1.08 & 1.10 & 0.73 \\
\hline 0.17 & 0.21 & 0.15 & 0.10 & 0.22 & 0.14 & 0.22 & 0.22 & 0.21 & 0.21 \\
\hline 0.17 & 0.17 & 0.15 & 0.19 & 0.14 & 0.17 & 0.13 & 0.16 & 0.10 & 0.10 \\
\hline 99.55 & 99.86 & 99.64 & 100.15 & 99.70 & 99.63 & 100.00 & 99.58 & 99.77 & 99.63 \\
\hline 11.27 & 10.98 & 12.48 & 12.66 & 15.65 & 19.12 & 18.44 & 21.51 & 20.38 & 24.82 \\
\hline 12.13 & 10.63 & 3.3 .36 & 14.95 & 16.54 & 17.79 & 17.53 & 15,66 & 16.43 & 18.42 \\
\hline 29.78 & ริา. 40 & 27.05 & 29.53 & 34.50 & 26.32 & 33.40 & 26,32 & 29.02 & 26.37 \\
\hline 22.58 & 23.20 & 24.95 & 23.77 & 16.52 & 20.22 & 15.77 & 19.89 & 19.73 & $\begin{array}{r}18.47 \\
(C 0.15)\end{array}$ \\
\hline 2.69 & 2.73 & 1.58 & 1.59 & 2.37 & 0.79 & 1.42 & 0.83 & 0.54 & \\
\hline 1.71 & 2.77 & 0.96 & $I, 05$ & 1.41 & 0.38 & 1.01 & 0.43 & 0.33 & \\
\hline 0.82 & 0.78 & 0.53 & $0.4 z$ & D. 84 & 0.40 & 0.28 & 0.37 & 0.18 & \\
\hline 8.23 & 8.46 & 8.54 & 7.17 & 4.42 & 5.22 & 4.76 & 5.27 & 5.35 & 4.73 \\
\hline 3.93 & 3.69 & 4.59 & 2,94 & 2.64 & 5.42 & 1.31 & 4.77 & 2.79 & 2.32 \\
\hline 3.59 & 3.36 & 2.78 & 3.47 & 2.34 & 1.78 & 3.89 & 2.12 & 2.74 & 2.57 \\
\hline 1,06 & 1.05 & 1.11 & 1.04 & 0.76 & 0.74 & 0.74 & 0.74 & 0.74 & 0.61 \\
\hline 0.39 & 0.39 & 0.33 & 0.44 & 0.33 & 0.39 & 0.30 & 0.37 & 0.23 & 0.23 \\
\hline 53.18 & 53.01 & 52.89 & 57.14 & 66.79 & 63.23 & 69.37 & 63.49 & 65.83 & 69.61 \\
\hline $\mathrm{C}-1$ & C-1. & $C-1$ & C-1 & $C-2$ & $C-2$ & $C-2$ & $C-2$ & $C-2$ & $C-2$ \\
\hline
\end{tabular}

euhedral or subhedral.

Quartz occurs interstitially among plagioclase and mafic minerals.

K-feldspar occurs interstitially among other minerals.

Quartz and K-feldspar content in subtype $\mathrm{C}-2$ rocks are higher than that in subtype $\mathrm{C}-1$ rocks.

Hornblende is mainly euhedral and sometimes subhedral, showing a "subophitic" relation. Generally it is green in color but rarely brownish green in the core. Poikilitic plagioclase inclusions are not rare. The relict cores of augite are rarely observed in the hornblende of subtype C-1.

Biotite occurs either in hornblende crystals or as isolated grain from horn- blende.

As accessory minerals, sphene and apatite occur in all three types. Opaque mineral also occurs in all rocks, but in subtype A-1 rocks it occurs in considerable amount.

\section{Modal compositions}

Fifty-two new modal analyses were made on the rocks of the three types. Average compositions of each division are shown in Table 1. All analysed compositions were plotted on quartz-K-feldsparplagioclase triangular diagram showing the nomenclature used in this paper (Fig. 3). In this figure only the compositional fields of type $\mathrm{B}$ and all subtypes and their average compositions are shown. As the figure shows, the field of subtype $\mathrm{C}-1$ is clearly separated from that of subtype $\mathrm{C}-2$. The fields of distribution of group $p$ and $h$ are not drawn because the fields of these groups are mostly overlapping.

The compositional fields and average compositions of the divisions shown in Table 1 are presented in (quartz $+\mathrm{K}$-feldspar)plagioclase-mafic minerals triangular diagram. (Fig. 4). Similar to Fig. 3, the fields of subtypes $\mathrm{C}-1$ and $\mathrm{C}-2$ are obviously separated. As the figure shows, the fields of distribution of $\mathrm{A} 2 \mathrm{~h}$ and $\mathrm{A} 3 \mathrm{~h}$ are separated from $A 2 p$ and $A 3 p$, respectively, according to the plagioclase/mafic mineral ratio. And, as Table 1 shows, hornblende in both A2h and $\mathrm{A} 3 \mathrm{~h}$ rocks is contained in large amount over 60 vol. $\%$ and attains a maximum content of about 80 vol. \%. This evidence suggests that many of group h rocks are originated from accumulation of hornblende. Subtype A-1 rocks, belonging to group $\mathrm{p}$, are relatively rich in opaque mineral as compared to the other divisions of type A rocks. This means that the 
mineral is somewhat accumulated.

In all three types, modal contents of biotite are unusually poorer than that of other plutonic bodies in the Kitakami mountains.

\section{Petrochemistry}

Twenty-nine new chemical analyses were made on the representative rocks of three types as shown in Table 2. As the table shows, $\mathrm{SiO}_{2}$ content varies continuously within a range from 41 to $67 \%$, and generally increases in the order of type or subtypes A-1, A-2, A-3, B, C-1 and C-2. Subtype A-1 rocks are very low in $\mathrm{SiO}_{2}$. Without exception, the following features are recognized: (1) Subtype A-2 rocks are lower in $\mathrm{SiO}_{2}$ and higher in $\mathrm{CaO}$ than subtype A-3 rocks; (2) B type rocks are lower in $\mathrm{SiO}_{2}$ and higher in $\mathrm{Fe}_{2} \mathrm{O}_{3}+\mathrm{FeO}$, $\mathrm{CaO}$ and $\mathrm{MgO}$ than type $\mathrm{C}$ rocks; (3) The rocks of subtype $\mathrm{C}-1$ are lower in $\mathrm{SiO}_{2}$ and higher in $\mathrm{Al}_{2} \mathrm{O}_{3}, \mathrm{Fe}_{2} \mathrm{O}_{3}+\mathrm{FeO}, \mathrm{MnO}, \mathrm{MgO}$ and $\mathrm{CaO}$ than those of subtype $\mathrm{C}-2$.

In subtype A-1 rocks and a part of subtypes A-2 and A-3 rocks normative nepheline less than $5 \%$ is calculated. Nevertheless, modal nepheline is absent. It is probably ascribed to normative nepheline contained in their modal hornblende.

Distinct discrepancy between subtypes $\mathrm{C}-1$ and $\mathrm{C}-2$ in Table 2 is reflected in their modal compositions (see Figs, 3 and 4).

Variations of $\mathrm{SiO}_{2}$ against major oxides are illustrated in Fig. 5. The variation trends of the Orikabe granitic body (Ishijima and Kato, 1971; Kato, 1972) and average granitic rocks of Japan (Aramaki et al., 1972) are also shown for comparison. As the figure shows, main oxides are plotted on smooth curves except $\mathrm{MgO}$ and $\mathrm{Al}_{2} \mathrm{O}_{3}$, where plots of type $A$ rocks are relatively dispersed.

When each rock type of the body is compared with that of the Orikabe body, alkalies are lower in types $A$ and $B$, but nearly equal in type $\mathrm{C}$. Type $\mathrm{A}$ is slightly higher in $\mathrm{CaO}$ but lower in $\mathrm{Fe}_{\mathbf{2}} \mathrm{O}_{\mathbf{3}}+\mathrm{FeO}$, whereas type $C$ is nearly equal in both compositions. Distinct differences are recognized in the $\mathrm{MgO}$ and $\mathrm{Al}_{2} \mathrm{O}_{3}$ contents
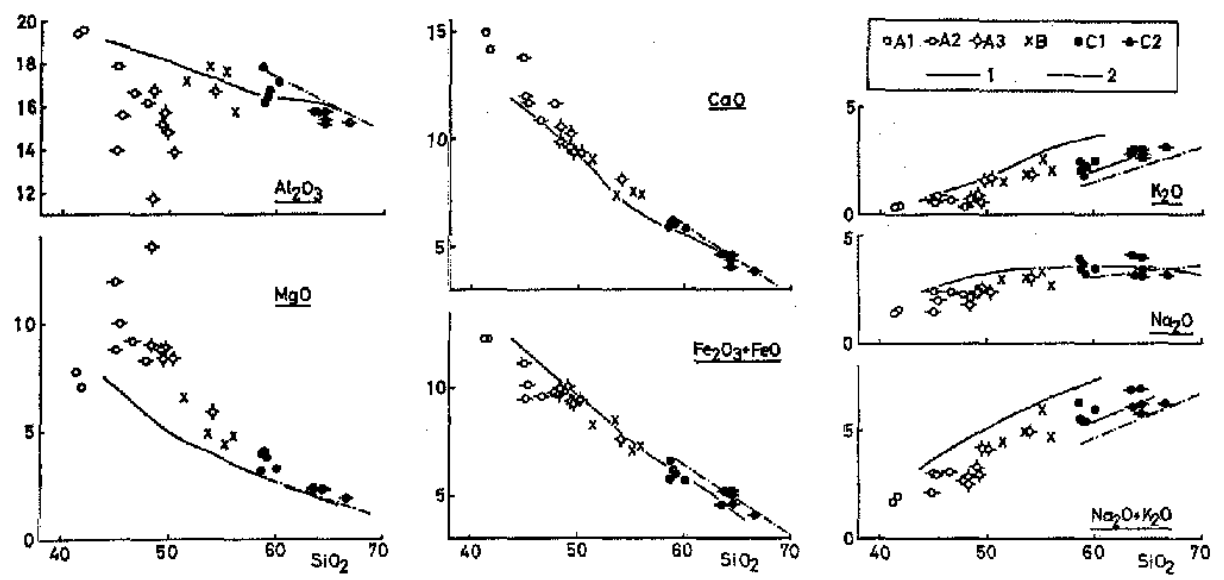

Fig. $5 \mathrm{SiO}_{2}$-oxides diagram.

1: Variation curves of the Orikabe granitic body (Ishijima and Kato, 1971; Kato, 1972); 2: Those of the Japanese granitic rocks (Aramaki et al., 1972) 
of subtypes $\mathrm{A}-2$ and $\mathrm{A}-3$ rocks. $\mathrm{MgO}$ is higher and $\mathrm{Al}_{2} \mathrm{O}_{3}$ is lower than in thase of the Orikabe rocks. In comparison with the Japanese average granitic rocks, on the other hand, type $\mathrm{C}$ rocks of this body are clearly higher in $\mathrm{MgO}$ and $\mathrm{K}_{2} \mathrm{O}$ contents whereas they are slightly lower in $\mathrm{Al}_{2} \mathrm{O}_{3}$, $\mathrm{CaO}$ and $\mathrm{Fe}_{2} \mathrm{O}_{3}$ and slightly higher in $\mathrm{Na}_{2} \mathrm{O}$. Although the $\mathrm{SiO}_{2}-\mathrm{TiO}_{2}$ diagram is not shown it has been observed that $\mathrm{TiO}_{2}$ content of type $\mathrm{C}$ rocks are clearly lower than that of Japanese average granitic rocks.

\section{Gomparison WITH OTHER BoDIES IN The Kitakami Mountains}

Katada et al. (1971) have proposed a new zonal arrangement of the Cretaceous granitic bodies, Kitakami mountains, on the basis of the field occurrences, petrography and petrochemistry. According to them, the Sakainokami body belongs to zone C. They are characterized by small size of rock bodies, solidification at shallower depth, remarkable variation of rock facies, wide range of rock variety (gabbroic to granodioritic), considerable amount of associated gabbroic rocks and more content of $\mathrm{Na}_{2} \mathrm{O}$ than $\mathrm{K}_{2} \mathrm{O}$. These general characteristics of zone $\mathrm{C}$ coincide with the characters of the Sakainokami plutonic body.

The features observed in hand specimens of subtype $\mathrm{C}-2$ rocks are similar to those of Tabashine, Orikabe and Hirota bodies in terms of medium grain-size, grayish color of rocks and pink color of K-feldspar (Kato, 1974).

\section{DisPeRsed Plot oN $\mathrm{SiO}_{2}$-MgO DIAG- RAM}

In order to analyse the dispersed plots of type $\mathrm{A}$ rocks in $\mathrm{SiO}_{\mathrm{a}}-\mathrm{MgO}$ diagram, the chernical compositions of analysed rocks are

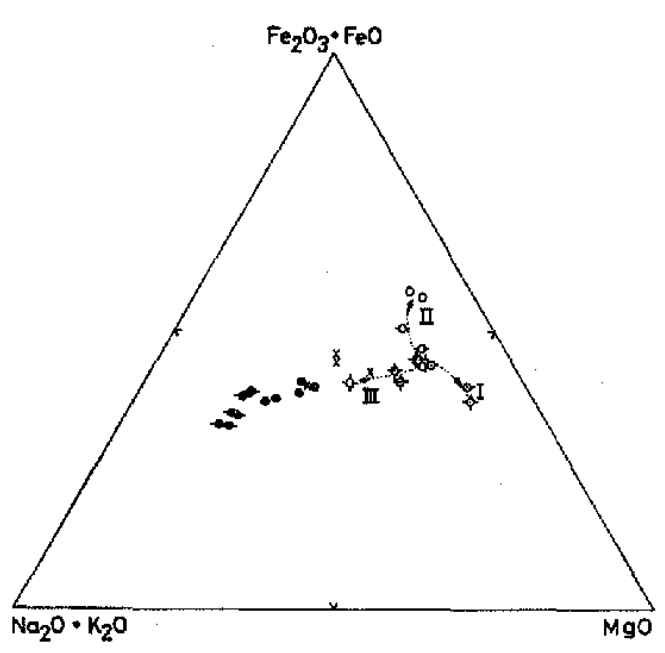

Fig. $6 \mathrm{MgO}-\left(\mathrm{Fe}_{2} \mathrm{O}_{3}+\mathrm{FeO}\right)-\left(\mathrm{Na}_{2} \mathrm{O}+\mathrm{K}_{2} \mathrm{O}\right)$ triangular diagram.

Symbols as in Fig. 5. As for subtypes A2 and $A-3$, symbols of group $h$ rocks are marked by central dots. Trends I and II and trend III are caused by accumulation and crystallization differentiation, respectively, See text.

plotted on a $\mathrm{MgO}-\left(\mathrm{Fe}_{2} \mathrm{O}_{3}+\mathrm{FeO}\right)-\left(\mathrm{Na}_{2} \mathrm{O}+\right.$ $\left.\mathrm{K}_{2} \mathrm{O}\right)$ triangular diagram in which symbols of A-h rocks are marked by dots (Fig. 6). As the figure shows, in type A rocks different trends are observed, namely: trend I, II and III. Trend III is calcalkaline trend. All plots on trend $I$ and II are group $h$ and $p$ rocks, respectively. Trend $\mathrm{I}$ is caused by accumulation of hornblende. On the other hand, trend II is ascribed to accumulation of opaque mineral, probably magnetite. This goes to say that contrast between trends I and II are due to accumulation of certain minerals. The degree of accumulation increases in the direction of the arrow.

In the $\mathrm{MgO}-\mathrm{SiO}_{2}$ diagram, only type $\mathrm{A}$ rocks are again plotted (Fig. 7). Group $h$ rocks are represented as circles with central dots. Their plots are connected by dotted line with arrow in the same order as in Fig. 6. The dispersed plot earlier 


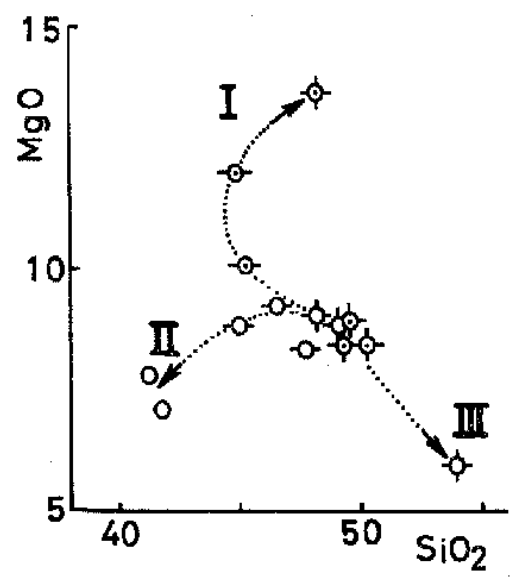

Fig. $7 \mathrm{SiO}_{2}$ - $\mathrm{MgO}$ diagram of A type rocks. Symbols as in Fig. 6. See text.

obtained in Fig. 5 now appears to be arranged in terms of trends I, II and III, similar to those obtained in the $\mathrm{MgO}-\left(\mathrm{Fe}_{2}\right.$ $\mathrm{O}+\mathrm{FeO})-\left(\mathrm{Na}_{2} \mathrm{O}+\mathrm{K}_{2} \mathrm{O}\right)$ diagram of Fig. 6 . Variation of $\mathrm{MgO}$ of all the three trends is generally controlled by modal content of hormblende.

Since chemical composition of minerals is indispensable in the consideration of the genesis of accumulation, further discussions on this matter is deferred for the next paper.

\section{AGKNOWLEDGEMENTS}

The authors thank Prof. Yoshio Ueda of Tohoku University for his encouragement. They wish also express their thanks to Dr. Masato Katada and Mr. Hiroshi Kanaya, Geological survey of Japan, for their kind facilities and benefical discussions at field survey. Sincere appreciation is extended to Assistant Prof. Hitoshi Onuki of the Tohoku University for his valuable suggestions. The authors are grateful to Mr. G.R. Balce of Tohoku University for his kindness in taking the trouble of correcting the English manuscripts. A part of expense of this study was defrayed by a grant from the Geodynamic Project of the Japanese Goverment Expenditure.

\section{REFERENGES}

Aramaki, S., Hirayama, K. and Nozawa, T. (1972), Chemical composition of Japanese granites, Part 2. Variation trends and average compostion of 1200 analyses. Jour. Geol. Soc. Japan, 78, 39-49.

Ishijima, M. and Kato, Y. (1971), On the Orikabe granitic body, Kitakami mountainland. $f$. Japan. Assoc. Miner. Petr. Econ. Geol., 65, 149-161 (in Japanese with English abstract).

Kanaya, H. (1974), Cretaceous granitic rocks in the Kitakami mountains-Petrography and zonal arrangement-. V. Potassium, thorium, uranium and magnetic susceptibility. Geol. Suvv. Japan Rep., 251, 90-120 (in Japanesc with English abstract).

Katada, M., Onuki, H., Kato, Y., Kanisawa, S, Ono, C. and Yoshii, M. (1971), Zonal arrangement of the Cretaceous granitic rocks, Kita+ kami mountainland. J. Japan. Assoc. Miner. Petw. Econ. Geol., 65, 230-245 (in Japanese with English abstract).

Kato, Y. (1972), Petrology of the Orikabe granitic body, Kitakami mountainland. J. Japan. Assoc. Miney. Petr. Econ. Geol., 67, 50-59 (in Japanese with English abstract).

- (1974), Petrology of the Tabashine granitic body, Kitakami mountains, northeastern Japan. J. Japan. Assoc: Miner. Petr. Econ. Geol., 69, 417-425. 


\section{北上山地, 㙼/神深成岩体の岩石化学}

$$
\text { 加袮鿆 三・浜 }
$$

䀩

堺ノ神岩体は北部北上山地に位置する白巠紀貫入岩体の一つで，野外々鏡下での钼察から，貫入の腯に A， B,

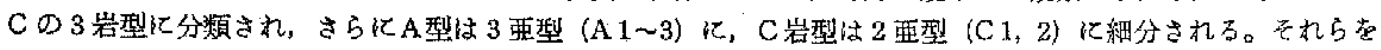
構成する代表的な岩石は次の通りである。

A1 かんらん石普通輝石普通角聞石珓机い岩

A2 普通輝石普通角閦石泣机い岩

A3 黒雲母普通角閃石斑れい岩

B 黒雲母普通角閅石斑机い岩, 閃緑岩

C 黒雲母普通角䦍石花崗閃緑岩

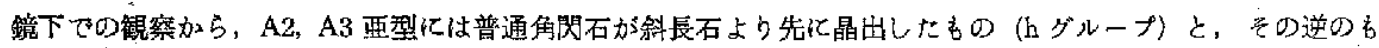
の( $\mathrm{p}$ グループ)とが認められる。前者のかなり多くと，後者の一部は，各種程度の結搨集積相である。

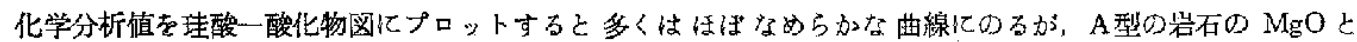

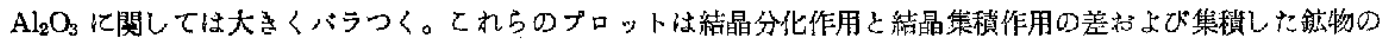
種剚の差て，計 3 種の曲線上㲸整理される。
Akatamori 赤田森
Oginosawa 覀, 沢
Osada 長田
Otaki 大滰
Takamine 高峰
Takasaki-yama 高崎山 